\title{
Ouder worden en duurzame inzetbaarheid op het werk
}

Annet de Lange, René Schalk en Beatrice van der Heijden

22.1 Inleiding - 382

22.2 Statistieken en empirische resultaten welzijn en arbeidsparticipatie ouderen $\mathbf{- 3 8 3}$

22.2.1 Empirische resultaten: leeftijdsgerelateerde veranderingen in belastbaarheid - 384

22.3 Operationalisatie ouder worden op het werk - 386

22.4 Leeftijdsverschillen in belastbaarheid en belasting: push en pull? - 389

22.4.1 Push- en pull-factoren? - 391

22.5 Interventies om duurzame inzetbaarheid van ouderen te bevorderen - 395

Aanbevolen literatuur - 398 
II 'Age appears to be best in four things, - old wood best to burn, old wine to drink, old friends to trust, and old authors to read' Alonso de Aragón (1470-1529) 《

\subsection{Inleiding}

Duurzame inzetbaarheid van oudere werknemers is een zeer belangrijk thema, omdat Nederland naast een sterke vergrijzing van de babyboomgeneratie (het cohort dat geboren is tussen 1946 en 1964) ook te maken heeft met een sterke ontgroening van de arbeidsmarkt. Deze ontwikkelingen zijn niet uniek voor Nederland, maar ook in breder internationaal kader zichtbaar. Om het Nederlandse pensioenstelsel betaalbaar te kunnen houden, en teneinde verlies van waardevolle kennis en ervaring door de uittreding van de babyboomgeneratie tegen te kunnen gaan, zullen oudere werknemers duurzaam inzetbaar moeten blijven op de arbeidsmarkt (De Lange e.a., 2011a). Echter, om dit daadwerkelijk te kunnen realiseren is het van belang om te weten wat duurzame inzetbaarheid precies inhoudt.

Uit de literatuur wordt duidelijk dat duurzame inzetbaarheid een multidimensioneel begrip is dat naar diverse arbeidsgerelateerde determinanten en uitkomsten verwijst. Van der Klink en collega's (2011; p. 347) definiëren duurzame inzetbaarheid bijvoorbeeld als:

I) het doorlopend beschikken over daadwerkelijk realiseerbare mogelijkheden en voorwaarden om te kunnen (blijven) functioneren in het huidige en in toekomstig werk, met behoud van gezondheid en welzijn. «

Uit deze definitie kunnen wij ten eerste opmaken dat duurzame inzetbaarheid een gezonde of degelijke werkcontext en een ondersteunende direct leidinggevende impliceert die werknemers in staat stelt om inzetbaar te kunnen blijven. Met andere woorden, duurzame inzetbaarheid begint met de context die gekarakteriseerd zou moeten worden door een gezonde werkomgeving met een stimulerende leidinggevende (zie H. 1, H. 2 en $>$ H. 9). Daarnaast verwijst de definitie naar de attitude en de motivatie van de individuele medewerker om de mogelijkheden en voorwaarden die de werkcontext biedt ook daadwerkelijk te benutten (Brouwer e.a., 2012). Er zijn ook definities beschikbaar die specifieke aspecten van duurzame inzetbaarheid benoemen. Volgens de Sociaal Economische Raad (SER, 2009) bestaat duurzame inzetbaarheid bijvoorbeeld uit de volgende drie specifieke elementen: vitaliteit, werkvermogen, en 'employability'. Het eerste element, vitaliteit, staat volgens Schaufeli en Bakker (zie $>$ H. 17) voor energiek, veerkrachtig, fit en onvermoeibaar door kunnen werken met een groot doorzettingsvermogen. Het tweede element, werkvermogen, verwijst naar de mate waarin men fysiek, psychisch (zoals motivatie om te werken) en sociaal in staat is om te werken. Tot slot verwijst 'employability' naar het vermogen om nu en in de toekomst verschillende werkzaamheden en functies adequaat te kunnen blijven vervullen, zowel in het eigen bedrijf als, indien nodig, in een ander bedrijf of andere sector. De definitie van Van der Heijde en Van der Heijden (2006) omvat bovendien het vermogen om, indien nodig, werk te creëren door het optimaal gebruiken van competenties. Zij onderscheiden vijf dimensies in hun operationalisatie van het concept 'employability'. De eerste dimensie betreft de 'beroepsexpertise' van een werknemer en omvat de domeinspecifieke kennis en vaardigheden die hij of zij bezit. De tweede dimensie, 'anticipatie en optimalisering', betreft het op een persoonlijke en creatieve manier voorbereiden op toekomstige werkveranderingen, teneinde te streven naar de best mogelijke functie- en loopbaanuitkomsten. 'Per- 
soonlijke flexibiliteit', als derde dimensie, verwijst naar het vermogen dat iemand heeft om zich aan te passen aan allerlei veranderingen op de interne en externe arbeidsmarkt, die niet direct betrekking hebben op het huidige functiedomein. De vierde dimensie, 'organisatiesensitiviteit', betreft de bekwaamheid om in verschillende sociale verbanden te participeren en te presteren, zoals de afdeling, de organisatie, teams, de beroepsgemeenschap, en andere netwerken, en impliceert het kunnen delen van verantwoordelijkheden, kennis, ervaringen, gevoelens, succes en falen, enzovoorts. Tot slot, de vijfde dimensie, 'balans', is gedefinieerd als een compromis vinden tussen allerlei belangen die de werkgever heeft versus de belangen van de werknemer, alsook tussen tegenstrijdige belangen van de werknemer zelf, zoals het spanningsveld tussen allerlei werk-, loopbaan- en privédoelen.

In dit hoofdstuk zullen wij, in overeenstemming met de hierboven vermelde definities, duurzame inzetbaarheid bespreken in termen van psychologisch welzijn (inclusief vitaliteit en motivatie om te werken), gezondheid, werkvermogen, 'employability', alsook in termen van werkgerelateerde uitval, via indicatoren zoals arbeidsparticipatie en pensionering.

Als zodanig is het doel van dit hoofdstuk het in kaart brengen van de relaties tussen ouder worden en duurzame inzetbaarheid op het werk. Meer specifiek wordt in dit hoofdstuk stilgestaan bij de volgende onderwerpen:

- belangrijke statistieken en empirische resultaten uit Nederland ( $\bullet$ par. 22.2);

- de operationalisatie van ouder worden op het werk ( $\downarrow$ par. 22.3);

- relevante theorieën ten aanzien van leeftijdsverschillen, belastbaarheid en belasting die meer informatie geven over de effecten van ouder worden op het werk ( $\downarrow$ par. 22.4);

- relevante interventies die ingezet kunnen worden om de duurzame inzetbaarheid van ouderen positief te beïnvloeden ( $\vee$ par. 22.5).

\subsection{Statistieken en empirische resultaten welzijn en arbeidsparticipatie ouderen}

In Nederland bestaan diverse statistieken en representatieve onderzoeken die een inzichtelijk beeld geven van het welzijn en de arbeidsparticipatie van ouderen. Het CBS beschikt over statistieken die de ontwikkelingen in de arbeidsparticipatie en het welzijn van ouderen weergeven. In 2008 was $15 \%$ van de Nederlanders 65 jaar of ouder, terwijl in 2040 te verwachten valt dat dit aantal gestegen zal zijn tot $27 \%$ (De Lange e.a., 2011a). Bovendien geven de statistieken een duidelijke toename in grijze druk op de arbeidsmarkt weer (het aantal 65-plussers als percentage van de bevolkingsgroep van 15-64 jaar). De netto-arbeidsparticipatie van personen van 50 tot 65 jaar is geleidelijk gestegen van 40\% in 1996 tot 57\% in 2009 (De Lange e.a., 2011a). Daarnaast dragen ouderen in vergelijking tot jongeren relatief meer bij aan het ziekteverzuim (in termen van verzuimduur) in Nederland (Nauta, De Bruin \& Cremer, 2004). Ook hebben de oudere werknemers relatief meer psychische klachten vanaf 45 jaar in vergelijking tot hun jongere collega's (zie - Figuur 22.1). Naast deze statistieken is het belangrijk om te kijken naar de resultaten met betrekking tot pensionering.

De gemiddelde pensioenleeftijd, dat wil zeggen de gemiddelde leeftijd waarop werknemers feitelijk met pensioen gaan, was 63 jaar in 2012, en circa $80 \%$ van de werknemers bleek met pensioen te zijn gegaan vóór hun 65ste jaar (De Lange e.a., 2011a). Daarnaast wijzen diverse onderzoeken uit dat oudere werknemers wel aangeven langer te willen doorwerken, maar feitelijk vaak toch eerder dan de gewenste leeftijd met pensioen gaan (Koppes e.a., 2011). Een relevant voorbeeld in dit opzicht is het grootschalige longitudinale onderzoek van het Nederlands In- 


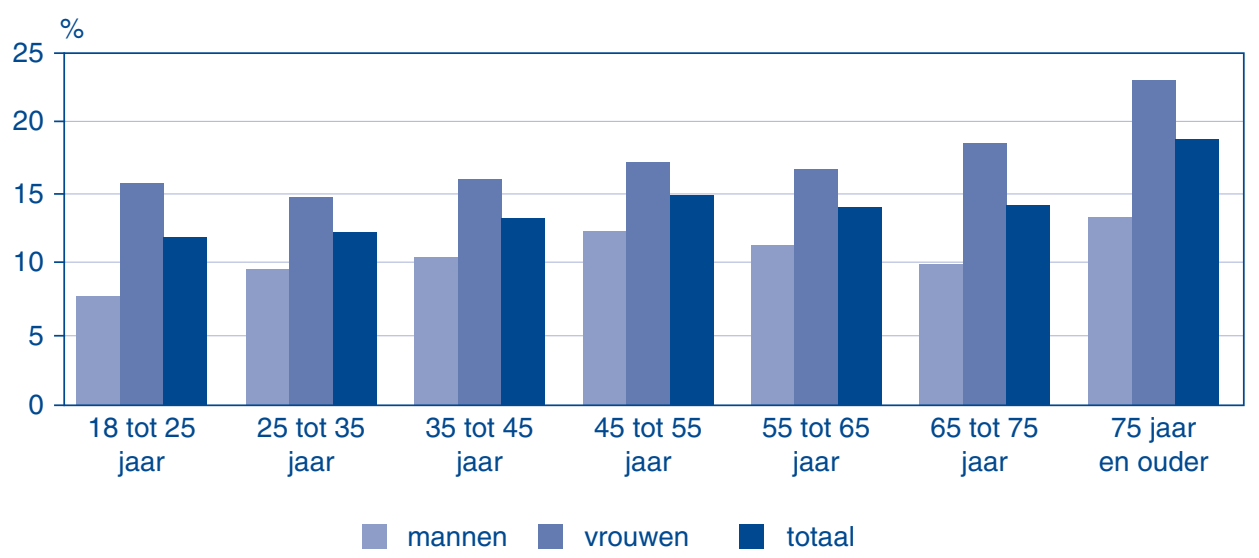

- Figuur 22.1 Psychische klachten naar geslacht en leeftijd. Bron: CBS.

terdisciplinair Demografisch Instituut (NIDI). Van de 1.687 ondervraagde oudere werknemers (van 50-60 jaar) werkzaam bij de rijksoverheid en enkele bedrijven gaf $78 \%$ uit het oudere cohort (geboren tussen 1947 en 1951) in 2001 aan van plan te zijn om te stoppen met werken voor het 65 ste levensjaar. In 2007 bleek dit percentage echter iets gedaald te zijn naar $66 \%$. Wat betreft de wensen van de werknemers om langer door te werken, rapporteerde $87 \%$ van de ouderen in 2001 niet te willen werken na het 65 ste levensjaar. In 2007 was dit percentage $78 \%$. Slechts 6\% van het cohort van oudere werknemers gaf in 2007 aan zeker te willen doorwerken na de pensioengerechtigde leeftijd. Verder blijken vooral de hoger opgeleide werknemers interesse te hebben voor langer doorwerken (Henkens, Van Dalen \& Van Solinge, 2009).

Samenvattend geven deze statistieken weer dat de overgrote meerderheid van de werknemers eerder stopt met werken dan de officiële pensioengerechtigde leeftijd en dat veel oudere werknemers niet tot hun 65ste of daarna willen of kunnen doorwerken. Daarnaast kunnen we constateren dat de oudere werknemers relatief gezien langer verzuimen en meer psychische klachten hebben in vergelijking met hun jongere collega's. De negatieve gevolgen van deze ontwikkelingen voor de arbeidsmarkt zijn moeilijk op te vangen gezien de lagere instroom van jongeren. Duurzame inzetbaarheid van oudere werknemers is hierdoor een belangrijk maatschappelijk vraagstuk geworden en staat ook hoog op de internationale wetenschappelijke agenda (Schalk e.a., 2010). In de volgende paragraaf zullen we nader in gaan op de belangrijkste empirische resultaten uit wetenschappelijk onderzoek over de verbanden tussen leeftijd en duurzame inzetbaarheid.

\subsubsection{Empirische resultaten: leeftijdsgerelateerde veranderingen in belastbaarheid}

De afgelopen jaren is er veel onderzoek gedaan naar verbanden tussen leeftijd enerzijds en duurzame inzetbaarheid en belastbaarheid anderzijds (zie Brouwer e.a., 2012, voor een overzicht). Het gaat te ver om in dit hoofdstuk alle verschenen studies in detail te bespreken, maar in - Tabel 22.1 trachten we de belangrijkste resultaten per indicator van duurzame inzetbaarheid samen te vatten. 
Tabel 22.1 Leeftijdsverschillen en indicatoren van duurzame inzetbaarheid

\begin{tabular}{|c|c|c|}
\hline $\begin{array}{l}\text { indicator duurzame } \\
\text { inzetbaarheid }\end{array}$ & leeftijdsverschillen & relevante voorbeelden \\
\hline $\begin{array}{l}\text { psychologisch wel- } \\
\text { zijn (+/-) }\end{array}$ & $\begin{array}{l}\text { Divers } \\
\text { Curvilineaire relaties met positieve } \\
\text { resultaten voor oudere werkne- } \\
\text { mers (Cunningham, De la Rosa, } \\
\& \text { Jex, 2008). Maar het CBS (2011) } \\
\text { geeft meeste psychische klachten } \\
\text { voor oudere Nederlandse werkne- } \\
\text { mers ( }>45 \text { jaar en met name }>75 \\
\text { jaar) weer. }\end{array}$ & $\begin{array}{l}\text { Curvilineaire relaties zijn gevonden voor } \\
\text { relaties tussen leeftijd en (intrinsieke) } \\
\text { arbeidssatisfactie en algemeen psycho- } \\
\text { logisch welzijn (Warr, 1992); en positieve } \\
\text { relaties tussen leeftijd en werkgerela- } \\
\text { teerde attitudes (Ng \& Feldman, 2010). } \\
\text { Verder rapporteren ouderen in interna- } \\
\text { tionaal vergelijkend onderzoek gemid- } \\
\text { deld minder burnout, maar in Nederland } \\
\text { meer burnout en andere psychische } \\
\text { klachten dan jongere werknemers } \\
\text { (Nauta e.a., 2004; zie H. 17). }\end{array}$ \\
\hline employability (-) & $\begin{array}{l}\text { Ja } \\
\text { Met name negatieve relaties tus- } \\
\text { sen leeftijd en met door leiding- } \\
\text { gevende beoordeelde 'employabi- } \\
\text { lity' (Van der Heijden, 2011). Geldt } \\
\text { ook voor eigen perceptie van } \\
\text { 'employability'. }\end{array}$ & $\begin{array}{l}\text { Voor oudere werknemer lager beoor- } \\
\text { deelde employability door leiding- } \\
\text { gevende met duidelijke effecten voor } \\
\text { loopbaanuitkomsten (Van der Heijden } \\
\text { e.a., 2009). Belangrijk punt is dat de } \\
\text { oudere vaak minder opleidingskansen } \\
\text { krijgt (Maurer, Wrenn \& Weiss, 2003). }\end{array}$ \\
\hline gezondheid (-) & $\begin{array}{l}\text { Ja } \\
\text { Ouderen relatief slechtere gezond- } \\
\text { heid, minder fysieke reserves } \\
\text { en grotere kans op sterfte dan } \\
\text { jongeren. }\end{array}$ & $\begin{array}{l}\text { Positieve relatie leeftijd en chronische } \\
\text { gezondheidsproblematiek (Koolhaas } \\
\text { e.a., 2010). Verder negatieve relatie } \\
\text { leeftijd met fysieke reserves, sensorische } \\
\text { functies, metabolisme en spiermassa } \\
\text { (Nauta e.a., 2006). }\end{array}$ \\
\hline werkvermogen (-) & $\begin{array}{l}\text { Ja } \\
\text { Ouderen relatief lager werk- } \\
\text { vermogen dan jongeren, maar } \\
\text { grote diversiteit in groep ouderen } \\
\text { (Ilmarinen, 2006). }\end{array}$ & $\begin{array}{l}\text { Veel studies geven negatieve relatie tus- } \\
\text { sen leeftijd en werkvermogen weer (zie } \\
\text { o.a. Costa \& Sartori, 2007). } \\
\text { Maar de scores van ouderen zijn wel } \\
\text { divers en er is ook een groep van } \\
\text { ouderen met een relatief voldoende en } \\
\text { stabiel werkvermogen over de tijd (Von } \\
\text { Bonsdorff e.a., 2011). }\end{array}$ \\
\hline $\begin{array}{l}\text { motivatie om langer } \\
\text { door te werken (-) }\end{array}$ & $\begin{array}{l}\text { Ja } \\
\text { Negatieve relaties }\end{array}$ & $\begin{array}{l}\text { Uit het overzicht van Kooij e.a. (2008) } \\
\text { wordt duidelijk dat veel leeftijdsge- } \\
\text { relateerde veranderingen negatief } \\
\text { samenhangen met de motivatie om } \\
\text { door te werken. }\end{array}$ \\
\hline $\begin{array}{l}\text { arbeidsparticipatie (-) } \\
\text { en pensionering (+). }\end{array}$ & $\begin{array}{l}\text { Ja } \\
\text { Lagere relatieve arbeidsparticipa- } \\
\text { tie ouderen dan jongeren. } \\
\text { Hogere leeftijd gaat samen met } \\
\text { grotere kans op pensionering. }\end{array}$ & $\begin{array}{l}\text { Participatie oudere werknemers (> } 45 \\
\text { jaar) ligt lager dan arbeidsparticipatie } \\
\text { van jongere vooral mannelijke werkne- } \\
\text { mers (Nauta e.a., 2006). } \\
\text { Duidelijke relatie tussen hogere leeftijd } \\
\text { en pensionering (Brouwer e.a., 2012). }\end{array}$ \\
\hline
\end{tabular}

Noot: +: over het algemeen positieve relatie met leeftijd; -: over het algemeen negatieve relatie met leeftijd; +/-: zowel positieve als negatieve relaties met leeftijd gevonden 
Tabel 22.1 geeft weer dat oudere werknemers gemiddeld een relatief lagere duurzame inzetbaarheid hebben dan jongere werknemers. Oudere werknemers rapporteren bijvoorbeeld minder fysieke reserves te hebben, zij ervaren eerder een afname in de vaardigheden die met zogenoemde vloeiende cognitieve vermogens samenhangen (zoals reactiesnelheid en ruimtelijke functies), zij hebben een groter risico op chronische gezondheidsproblematiek, een relatief lager werkvermogen en een lagere motivatie om door te werken wanneer de pensioengerechtigde leeftijd in zicht komt (zie - Tabel 22.1 voor de referenties). Bovendien vallen oudere werknemers relatief sneller uit het arbeidsproces via de route van vervroegde pensionering of arbeidsongeschiktheid, of als gevolg van psychische klachten. Verder is er sprake van achteruitgang in zien, ruiken en horen, fysieke kracht en snelheid.

Over het algemeen is er echter sprake van een grote diversiteit in de groep oudere werknemers en zijn de gevonden veranderingen met leeftijd niet van toepassing op alle ouderen. De hierboven vermelde negatieve uitkomsten lijken sterker te zijn voor oudere werknemers met een lagere opleiding, voor vrouwen en voor allochtonen (Nauta e.a., 2006).

Daarentegen zijn er ook enkele positieve trends waarneembaar met het ouder worden. De grotendeels automatische, op kennis gebaseerde en gekristalliseerde cognitieve vaardigheden (zoals verbale vaardigheden) gaan er bijvoorbeeld tot het 65 ste jaar op vooruit. In dit verband kunnen ook genoemd worden de zogenoemde 'scripts' of cognitieve structuren die het geheugen sturen (bijv. voor een bepaalde werktaak). Een script maakt het mogelijk om een bepaalde taak min of meer automatisch af te handelen (Schabracq, 1998). Daarnaast zijn oudere werknemers relatief meer tevreden met hun werk in vergelijking tot hun jongere collega's, en hebben zij duidelijk meer ervaring en senioriteit (De Lange e.a., 2010a). Om deze verschillen tussen jongeren en ouderen en de diversiteit in het ouder worden verder te kunnen begrijpen, is het wenselijk om uitgebreider aandacht te besteden aan de operationalisatie van het concept 'ouder worden op het werk'.

\subsection{Operationalisatie ouder worden op het werk}

Zowel in de literatuur als in de praktijk wordt 'oud zijn' meestal gebaseerd op iemands kalenderleeftijd, waarbij de scheidslijn, afhankelijk van de context en het type studie, kan variëren van 40, 45 tot zelfs 75 jaar. Uit eerder onderzoek is bovendien gebleken dat ouder worden of leeftijd geen eenduidige factor is en als een containerbegrip fungeert voor verschillende betekenisvolle onderliggende processen. Meer specifiek verwijst ouder worden op het werk naar allerlei cognitieve, psychologische, sociale, fysieke en maatschappelijke veranderingen die men ondergaat in het werk gedurende de levensloop (De Lange e.a., 2006).

Het proces van het ouder worden verloopt niet bij iedere persoon op dezelfde manier. Er is namelijk sprake van verschillende soorten verandering en schijnbaar tegenstrijdige processen bij het ouder worden op het werk. Deze kenmerkende aspecten van het ouder worden kunnen als volgt worden samengevat:

1. Stabiliteit versus verandering

Ouder worden wordt gekenmerkt door zowel stabiliteit als verandering. Bijvoorbeeld, de persoonlijkheid van werknemers blijft relatief stabiel in de tijd, terwijl hun duurzame inzetbaarheid zowel in positieve als in negatieve zin kan veranderen in de tijd. Deze veranderingen kunnen soepel verlopen, of juist meer abrupt of stapsgewijs optreden. Hierdoor is het van belang meer te weten te komen over welk type verandering men in kaart wil brengen, en hoe men dit het beste in de tijd kan onderzoeken (Schalk e.a., 2011; zie ook $>$ H. 10). Zo zou er in toekomstig empirisch onderzoek meer aandacht moeten ko- 
men voor leeftijdsgerelateerde veranderingen in procesvariabelen (zoals herstelbehoefte, tijdsperspectief, motivatie, identiteit) die intra-individuele veranderingen in werkgedrag kunnen verklaren. Voor een werkgever is het bijvoorbeeld niet alleen van belang te weten dat een oudere werknemer, die hetzelfde werk blijft doen, in de loop van de tijd waarschijnlijk een lager werkvermogen zal ontwikkelen. De werkgever zal ook willen weten waardoor deze afname ontstaat en wat de mogelijkheden zijn om dit proces te stoppen of om te keren. Een onderzoeker of adviseur kan in dit geval nagaan of leeftijdsgerelateerde veranderingen, zoals een verminderde fysieke gezondheid of een verminderd tijdsperspectief op het werk, deze afname in werkvermogen (gedeeltelijk) kunnen verklaren. Ook moeten we meer inzicht krijgen in de vraag hoe motieven, persoonlijke voorkeuren, copingstrategieën, attitudes en emoties veranderen in de tijd. Ten slotte is het belangrijk om na te gaan hoe oudere werknemers eventuele afnamen in prestaties en inzetbaarheid zelf kunnen compenseren.

2. Normatieve leeftijdsgerelateerde versus non-normatieve veranderingen

Normatieve leeftijdsgerelateerde veranderingen zijn gangbare leeftijdsgerelateerde veranderingen die voor veel werknemers opgaan (zoals de menopauze voor oudere vrouwen), terwijl non-normatieve invloeden meer op toevalsbasis voor sommige mensen optreden, zoals het winnen van een loterij of het krijgen van een ongeluk (Cavanaugh \& BlanchardFields, 2011).

3. Inter-individuele diversiteit

Door de eerdergenoemde kenmerken van veroudering en vanwege het feit dat onze arbeidsmarkt steeds gevarieerder wordt, is er ook meer diversiteit in duurzame inzetbaarheid, werk en werkattitudes zichtbaar binnen de groep ouderen die actief zijn op de arbeidsmarkt. Deze diversiteit is te verklaren door het feit dat de uitkomsten van het ouder worden op het werk bepaald worden door de unieke interactie tussen biologische factoren (genetische opmaak), psychologische factoren (zoals persoonlijkheid, emotionele ervaringen, enz.), en socioculturele factoren (maatschappelijke context), die tezamen een specifiek resultaat opleveren voor een individuele werknemer (Cavanaugh \& BlanchardFields, 2011).

4. (On)zichtbare interne en externe veranderingen

Daarnaast zijn de positieve en negatieve veranderingen ten aanzien van het ouder worden op het werk relatief meer (bijv. rimpels, grijs haar) of minder zichtbaar (bijv. chronische ziekte, afname fysieke reserves), en van meer of minder betekenis voor het individu zelf. Zo kunnen we een onderscheid maken tussen interne veranderingen (of subjectieve ervaringen) enerzijds, en veranderingen die pas betekenis krijgen in een sociale context (externe verandering, zoals negatievere beeldvorming over ouder worden door anderen) anderzijds. Deze veranderingen kunnen bepaald worden op een persoonsgebaseerde manier (zoals subjectieve leeftijd) of op een contextgebaseerde manier (zoals stereotypen van collega's). Juist de relatief meer onzichtbare processen in een sociale context zijn tot dusverre relatief onderbelicht gebleven, maar worden van grote invloed geacht op de duurzame inzetbaarheid van oudere werknemers. Zij zullen daarom hieronder nader toegelicht worden. - Figuur 22.2 vat de belangrijkste leeftijdsgerelateerde veranderingen samen; de verticale orthogonale as geeft de mate waarin leeftijdsveranderingen intern of extern waargenomen worden weer, terwijl de horizontale as de betekenis of valentie van de verandering weergeeft in termen van verlies of groei. Bijvoorbeeld een interne verandering die toeneemt naarmate we ouder worden is opgedane ervaring, terwijl onze fysieke interne reserves juist afnemen naarmate we ouder worden. In de sociale context zijn deze typen veranderingen ook te onderscheiden. Bijvoorbeeld werknemers die ouder worden 


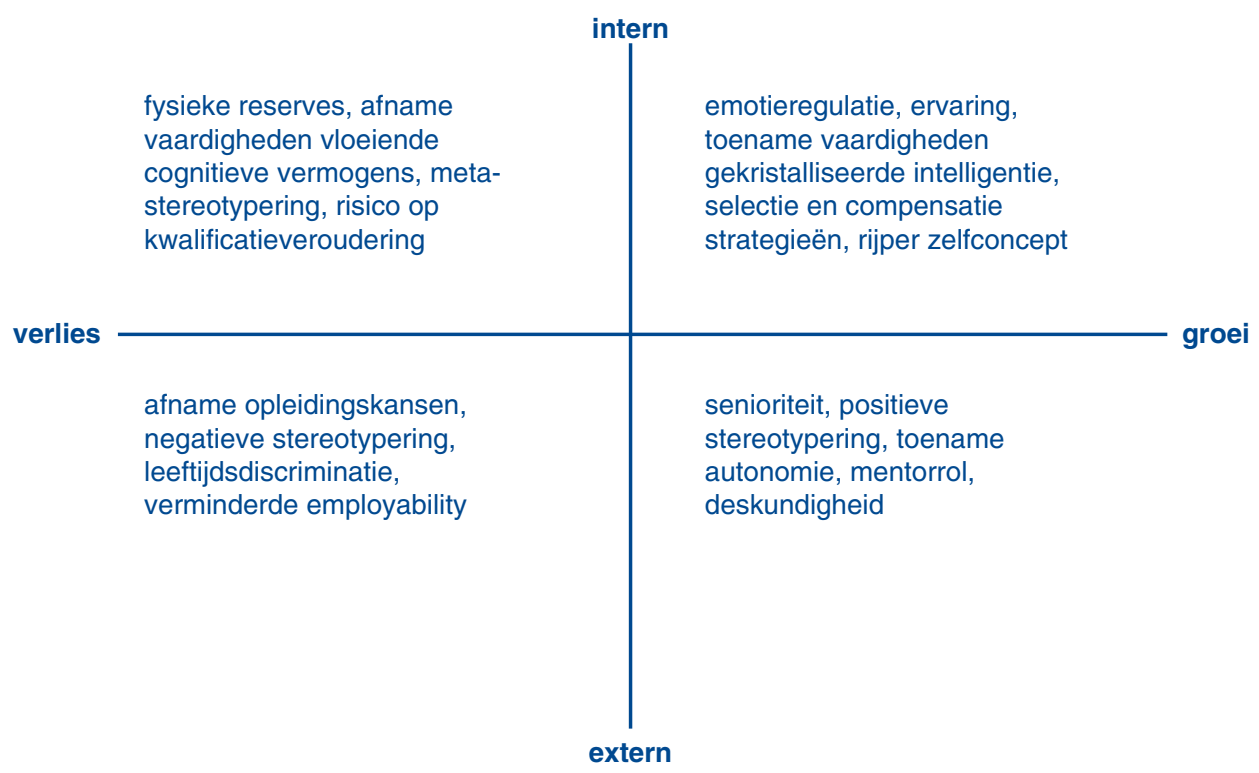

- Figuur 22.2 Voorbeelden van positieve en negatieve interne en externe veranderingen van ouder worden op het werk.

krijgen te maken met meer risico's voor leeftijdsdiscriminatie (een teken van verlies), maar hebben veelal ook meer autonomie in hun werk gerealiseerd (een teken van mogelijkheden of groei).

Samengevat geven de eerdere resultaten voor duurzame inzetbaarheid (zie $\mathbf{0}$ Tabel 22.1) en de verschillende kwadranten in - Figuur 22.2 weer dat ouder worden een complex begrip is en gepaard gaat met positieve veranderingen, maar ook met risico's in termen van belastbaarheid op het werk. Hierbij kan men leeftijd vaststellen via kalenderleeftijd, maar is het ook mogelijk, en naar verwachting meer informatief, om de onderliggende processen en verschillen in belastbaarheid onder ouderen te meten (De Lange e.a., 2006). - Figuur 22.3 geeft een grafisch overzicht van verschillende operationalisaties van het begrip ouder worden weer, met per type operationalisatie een aantal voorbeeldindicatoren.

Andere manieren om naar ouder worden op het werk te kijken, dan de meest gangbare operationalisatie 'chronologische leeftijd' (kalenderleeftijd), zijn bijvoorbeeld iemands organisatieleeftijd of prestatieleeftijd, die verwijst naar de mate waarin mensen zich hebben ontwikkeld tot op een bepaald punt in hun loopbaan, en hoe goed hun werkprestaties en competenties op dat moment zijn. Dit kan gemeten worden met behulp van indicatoren als vakmanschap en jaren dienstervaring. Een andere leeftijdsmaat is de psychosociale beleving van ouder worden, hetgeen verwijst naar de percepties die mensen zelf, alsook hun omgeving, hebben van hoe oud of hoe jong men is, en de gevolgen die dit heeft voor iemands functioneren. Dit type indicator kan gemeten worden met behulp van variabelen zoals beeldvorming over de oudere werknemer, subjectief tijdsperspectief (bijv. hoe ver kijkt iemand vooruit) en relatieve leeftijd (hoe oud ben $\mathrm{ik}$ in vergelijking tot bijvoorbeeld mijn teamgenoten of mijn leidinggevende).

Een andere leeftijdsmaat die meer betrekking heeft op de fysieke en cognitieve veranderingen is functionele leeftijd, die gemeten kan worden met behulp van variabelen als gezondheid 


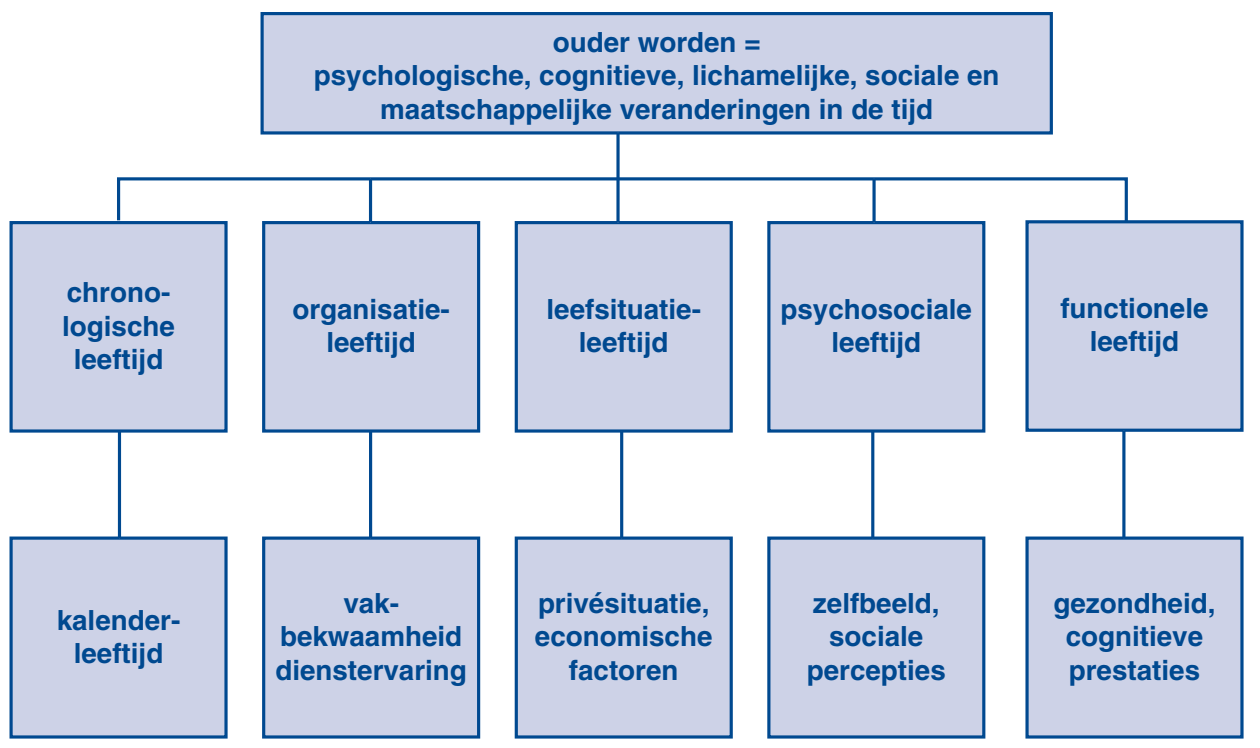

- Figuur 22.3 Operationalisaties van ouder worden op het werk (De Lange e.a., 2006).

en werkvermogen. Ook kunnen werknemers gedurende de levensloop belangrijke ontwikkelingen buiten het werk ervaren. Denk bijvoorbeeld aan gebeurtenissen zoals kinderen die het ouderlijk huis verlaten, aanpassingen in de partnerrelatie, scheidingen, ziekte en dood van naasten, nieuwe verbintenissen, en nieuwe bestedingen van de vrije tijd. Deze betekenisvolle levensloopveranderingen kunnen gemeten worden via de leefsituatieleeftijd (thuissituatie, economische situatie; zie - Figuur 22.3). De leefsituatieleeftijd verwijst naar hoe mensen op een bepaald punt in hun levensloop hun privésituatie hebben ingericht en welke gevolgen dat heeft voor de tijd en aandacht die zij aan hun werk besteden.

Kooij e.a. (2008) hebben deze verschillende typen operationalisaties van ouder worden op het werk in verband gebracht met de motivatie om langer door te werken en vonden vooral aanwijzingen dat deze motivatie afneemt op hogere leeftijd. Dit impliceert dat het van groot belang is om meer aandacht te besteden aan het ontwikkelen van interventies of maatregelen die duurzame inzetbaarheid bevorderen. Teneinde meer grip te krijgen op mogelijke ingangen voor interventies en maatregelen gaan we in de volgende sectie in op theorievorming op het terrein van ouder worden en werk. Daarna zullen we ingaan op concrete mogelijkheden die werkgevers hebben om duurzame inzetbaarheid van hun arbeidspotentieel te bewaken.

\subsection{Leeftijdsverschillen in belastbaarheid en belasting: push en pull?}

Om de eerder vermelde leeftijdsverschillen in duurzame inzetbaarheid van oudere versus jongere werknemers beter te kunnen begrijpen, is het nodig meer kennis te nemen van relevante wetenschappelijke theorieën op het terrein van ouder worden en werk. In deze paragraaf gaan wij daarom in op een aantal relevante levensloop- en arbeidspsychologische theorieën (zie ook $\rightarrow$ H. 2).

De levenslooptheorieën richten zich met name op de leeftijdsveranderingen in het functioneren en beschrijven de psychologische effecten die ouder worden met zich meebrengen. 
Volgens de levenslooptheorieën hebben ouderen te maken met natuurlijke verliezen (zoals een afname in fysieke vermogens; Kanfer \& Ackerman, 2004) en zullen zij streven naar het voorkomen van verdere verliezen en behoud van hun beschikbare hulpbronnen en niveau van functioneren (Baltes, Staudinger \& Lindenberger, 1999). Om duurzaam inzetbaar te blijven, zullen ouderen meer compensatiegedrag vertonen of op zoek gaan naar andere mogelijkheden (bijv. minder fysieke intensieve taken uitzoeken of meer herstelmogelijkheden creëren) om hun controlegevoel en zelfconcept te behouden (Heckhausen \& Shultz, 1995).

Een belangrijk voorbeeld van een levenslooptheorie is het Selection, Optimization with Compensation-model van Baltes e.a. (1999). Volgens deze theorie is succesvol ouder worden mogelijk via het inzetten van de juiste selectie- ('ik focus op specifieke werktaken'), optimalisatie- ('ik zorg voor ergonomische aanpassingen in mijn werksetting') en compensatie-strategieen ('ik neem meer tijd voor deze cognitieve taak'). Deze visie geeft weer dat oudere werknemers geen passieve toeschouwers zijn op het werk en duurzaam inzetbaar kunnen blijven via het inzetten van hun opgebouwde expertise en relevante copingstrategieën.

Een andere invloedrijke levenslooptheorie is de socio-emotionele selectiviteittheorie van Carstensen (1992). In deze theorie is het variabele tijdsperspectief een belangrijke factor die met leeftijd en doelgericht gedrag samenhangt. Volgens deze theorie ondergaan mensen een verandering in waargenomen tijdsperspectief naarmate zij ouder worden, en zullen zij doelen nastreven die passen bij het waargenomen tijdsperspectief dat mensen op een bepaald moment hebben. Meer specifiek wordt verondersteld dat jongere werknemers met een open ('tijd vanaf geboorte') tijdsperspectief gemotiveerd worden door langetermijnkennis en groeigerelateerde doelen (zoals het aanleren van nieuwe vaardigheden). Oudere werknemers, daarentegen, ervaren doorgaans een meer gesloten ('tijd tot de dood') tijdsperspectief, en zullen daardoor gemotiveerd worden door kortetermijn- en emotiegerelateerde doelen (zoals het verdiepen van bestaande sociale relaties). Zo werd in een studie van Fung en Carstenen (2003) bijvoorbeeld gewerkt met verschillende marketingteksten voor producten waar jongeren en ouderen uit konden kiezen. De marketingteksten benadrukten emoties ('blijf gezond voor je dierbaren') of langetermijntijdsdimensies ('blijf gezond voor een mooie toekomst'). Het onderzoek gaf aan dat de ouderen significant meer informatie en type producten wisten te onthouden wanneer de marketing emotiegericht was. In een follow-up studie werden de ouderen echter geconfronteerd met een tekst die aangaf dat zij twintig jaar langer en gezond zouden kunnen leven. Na deze tijdsmanipulatie bleken de resultaten tussen de jongeren en ouderen ten aanzien van hun voorkeur voor emotiegerichte marketing van producten niet meer significant. Dit onderzoek toont dus aan dat tijdsperspectief een interessante leeftijdsgerelateerde moderator is die de hierboven beschreven leeftijdsverschillen op het werk nader zou kunnen verklaren.

Inmiddels zijn meer interessante tijdsperspectiefonderzoeken verschenen die dit idee bevestigen. Een voorbeeld betreft de verschillen in waargenomen reacties na een psychologische contractbreuk. Van psychologische contractbreuk is sprake als een werknemer het idee heeft dat de organisatie haar verplichtingen ten opzichte van de werknemer niet na is gekomen. Een meta-analyse van Bal e.a. (2008) gaf aan dat ouderen, in vergelijking met jongeren, minder sterk reageren op psychologische contractbreuk. Een recent onderzoek onder oudere werknemers (De Lange e.a., 2011b) heeft aangetoond dat het hebben van een gesloten tijdsperspectief een verklaring kan bieden voor deze minder sterke reacties van ouderen op psychologisch contractbreuk. Met deze uitkomsten wordt duidelijk dat leeftijdsgerelateerde processen meegenomen dienen te worden in toekomstig onderzoek naar het psychologisch contract.

Een derde levenslooptheorie die relevant is in dit verband, gaat in op de sociale dimensie van het ouder worden op het werk. Onderzoek op het terrein van 'relational demography' (Tsui, Yin \& Egan, 1995) laat zien dat oudere werknemers die rapporteren aan een jongere 
leidinggevende negatiever beoordeeld worden wat betreft hun competenties en toekomstige inzetbaarheid in vergelijking met hun jongere collega's (Van der Heijden, 2012). Meer specifiek veroorzaakt de status-incongruentie, dat wil zeggen een situatie waarin een chef jonger is dan zijn of haar ondergeschikte, slechtere beoordelingen van de medewerker. Deze negatieve effecten van directionele leeftijdsverschillen blijken overigens niet gemakkelijk gebufferd te kunnen worden door bijvoorbeeld leiderschapskwaliteiten of door een leeftijdsbewust personeelsbeleid, blijkens de uitkomsten van onderzoek naar mogelijke interactie-effecten in dezen. De stereotypen zitten als het ware zo sterk verankerd in de hoofden van de managers dat ze nauwelijks te bestrijden zijn.

\subsubsection{Push-en pull-factoren?}

Naast de verschillen tussen jongere en oudere werknemers in psychologische en fysiologische belastbaarheid en duurzame inzetbaarheid zijn er ook verschillen in de mate van belasting die de ouderen ervaren. In veel gevallen is vroegtijdig vertrek van oudere werknemers namelijk een gevolg van een ongewenst proces met - simultaan - verschillende onderliggende oorzaken, de zogenoemde 'push'- en 'pull'-factoren (Van der Heijden \& De Lange, 2011). - Figuur 22.4 geeft de belangrijkste factoren weer die op macro-, organisatie-, werk- en individueel niveau van invloed zijn op de duurzame inzetbaarheid van oudere werknemers. Push-factoren omvatten negatieve aspecten die ervoor zorgen dat mensen een negatief oordeel over hun werk vormen (bijv. conflicten op het werk, of een slechte relatie met de leidinggevende). Deze factoren kunnen net als stressoren en geleverde inspanningen (zie $>$ H. 2) een sterke invloed hebben op de mentale en fysieke veerkracht en op de herstelbehoefte van de oudere werknemer. Pull-factoren zijn aantrekkelijke interne of externe prikkels die extra hulpbronnen kunnen opleveren voor oudere werknemers om hun veerkracht te optimaliseren en de belastbaarheid en duurzame inzetbaarheid op het werk te faciliteren (bijv. een opleiding volgen of een ondersteunende leidinggevende hebben). Een belangrijk uitgangspunt hierbij is het feit dat de oudere werknemer, in vergelijking tot jongere werknemers, meer risico's ervaart in termen van verlaagde belastbaarheid en dat hij of zij meer negatieve invloed ondervindt van andere belastende factoren (zoals negatieve beeldvorming over oudere werknemers). De uitdaging van succesvol ouder worden op het werk ligt dan ook in het effectief reguleren van de interne en externe push-factoren en een actieve bevordering van de pull-factoren, zodat extra verliezen in termen van belastbaarheid en inzetbaarheid voorkomen kunnen worden (Baltes e.a., 1999; Meijman \& Mulder, 1998). Hieronder staan wij gezien de beperkte ruimte in dit hoofdstuk alleen stil bij een aantal belangrijke belastende push-factoren voor oudere werknemers (zie • Figuur 22.4 voor een schematische samenvatting; zie ook Van der Heijden \& De Lange, 2011 voor informatie over mogelijke pull-factoren).

\section{Macroniveau}

Push-factoren voor oudere werknemers zijn te vinden op macro-, organisatie-, arbeidsomstandigheden- en individueel niveau. Op macroniveau heeft de oudere werknemer te maken met verschillende maatschappelijke ontwikkelingen zoals snelle technologische veranderingen, veranderende arbeidsvoorwaarden en een negatieve beeldvorming over ouder worden in de samenleving. Als gevolg van de zogenoemde snelle technologische veranderingen kunnen de vaardigheden van oudere werknemers achter raken bij wat vereist is, vooral in een situatie waarin tijdige, aanvullende training of scholing ontbreekt. Hierdoor bestaat het risico op kwalificatieveroudering of obsoletie. Het betreft echter vaak geen onwil aan de kant van de oudere 


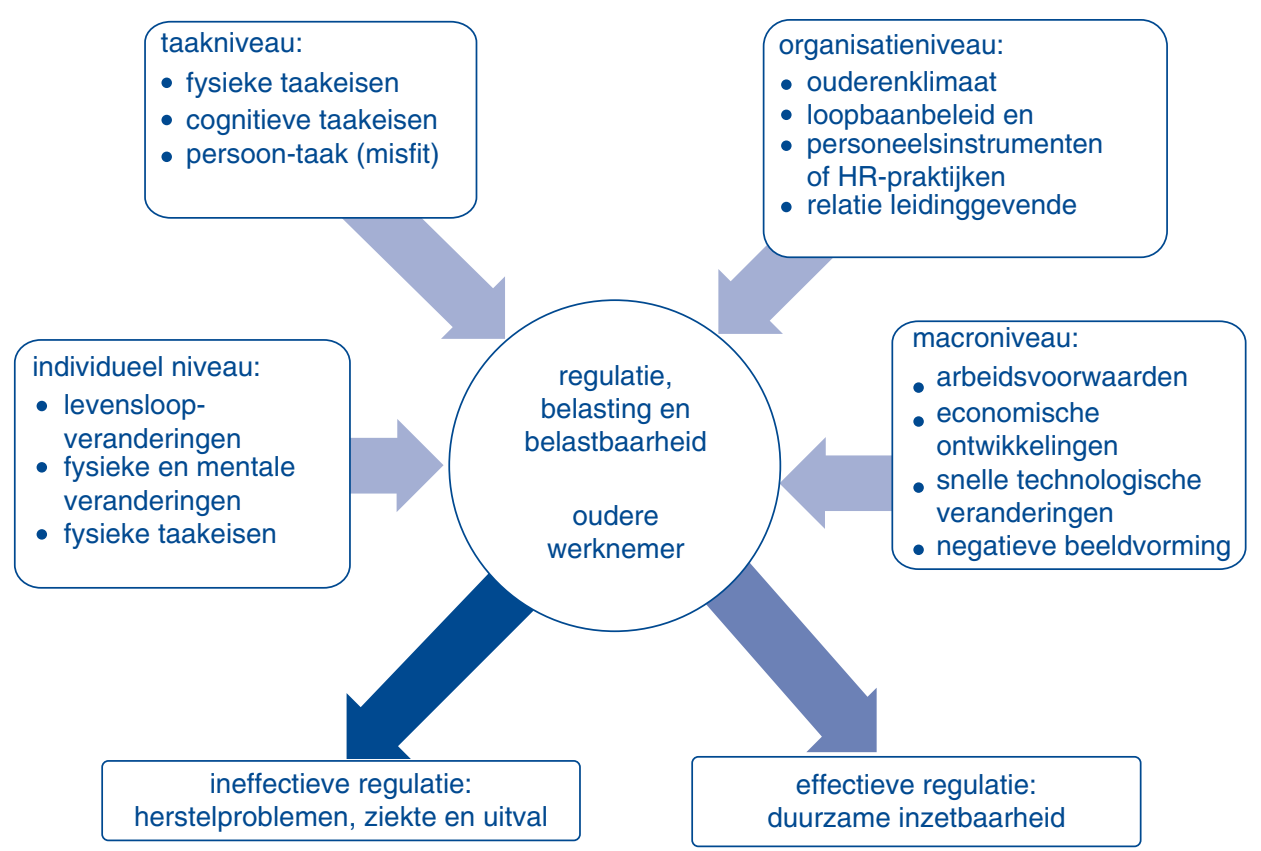

- Figuur 22.4 Model duurzame inzetbaarheid ouder wordende werknemer: effectieve regulatie van pushfactoren ten aanzien van werken.

werknemer. Eerder onderzoek heeft immers aangetoond dat oudere werknemers niet significant van hun jongere collega's verschillen wat betreft de mate waarin zij gemotiveerd zijn om nieuwe vaardigheden aan te leren (De Lange e.a., 2005). Werkgevers moeten zorgen voor een adequaat aanbod van opleidingsmogelijkheden om de duurzame inzetbaarheid van hun ouder wordende personeel te bewaken.

\section{Veranderende arbeidsvoorwaarden, economische ontwikkelingen en technologische veranderingen}

Door veranderingen in de economische ontwikkeling zijn er bijvoorbeeld schommelingen in het aanbod van beschikbare banen en in de mobiliteit van werknemers. Voor oudere werknemers zal het in een situatie van economische recessie lastig zijn om van baan te veranderen, dan wel om een nieuwe baan te vinden bij werkloosheid. Op het terrein van arbeidsvoorwaarden treden ook verschuivingen op, denk bijvoorbeeld aan de zogenoemde ontziemaatregelen (zoals extra verlofdagen) voor oudere werknemers die steeds meer uit de bestaande cao's worden geschrapt. Ook constateren we verdergaande vormen van internationalisering, informatisering, informalisering, individualisering en intensivering op de arbeidsmarkt, en verdergaande implementatie van vormen van Het Nieuwe Werken (zoals telewerken om tijds- en plaatsonafhankelijk werken mogelijk te maken), die voor velen de noodzaak tot het zoeken van een nieuwe balans tussen werk en privé, en hiermee het bewaken van hun belastbaarheid, verder onderstrepen (zie ook Peters e.a., 2011).

\section{Negatieve beeldvorming}

Negatieve beeldvorming en leeftijdsnormen in de samenleving vormen een hardnekkige groep van push-factoren die op verschillende niveaus in het werk van invloed zijn op de inzetbaarheid van oudere werknemers. Ouder worden is in de westerse wereld omgeven met stereoty- 
pen en vooroordelen. Ondanks de grote individuele verschillen tussen oudere medewerkers leidt dit ertoe dat oudere medewerkers worden gezien als een min of meer uniforme groep, gekenmerkt door geringe flexibiliteit en productiviteit, alsook door conservatisme, bitterheid, afhankelijkheid en passiviteit (Vrugt \& Schabracq, 1996). Boerlijst, Van der Heijden en Van Assen (1993) vonden in een grootschalig onderzoek naar de percepties en stereotiepe beelden (een negatieve attitude van de direct leidinggevende en andere leden van het managementteam ten aanzien van de oudere werknemer) van leidinggevenden over hun ondergeschikten, dat 40-plussers minder ambitieus zouden zijn, duurder, hun prestaties en hun innoverend vermogen zouden afnemen, hun kennis onderhevig zou zijn aan erosie, minder flexibel zouden zijn, minder creatief, star, en gefrustreerd zouden zijn. Een andere interessante studie in dit verband betreft het onderzoek van Van Dalen, Henkens en Schippers (2010) naar de beelden over de productiviteit van werknemers waarin grote verschillen werden aangetoond tussen jong en oud. Jonge werknemers $(<35$ jaar) worden in hoge mate geassocieerd met begrippen als flexibel, opleidingsbereid, vaardig met nieuwe technologieën en een hoge mate van fysieke belastbaarheid. Op 'zachte' kwaliteiten als betrokkenheid en betrouwbaarheid blijken dezelfde jongeren veel minder gunstig te scoren. Twee processen zijn hier van belang. Ten eerste leidt deze stereotypering ertoe dat ouderen verantwoordelijk worden gesteld voor hun problemen en de oplossing daarvan, terwijl de organisatie kan vasthouden aan een gunstig beeld van zichzelf. Oplossingen als technologische, organisatiekundige en ergonomische aanpassingen van de werkplek, functieherontwerp, trainingsprogramma's en beter loopbaanbeleid kunnen zo geheel uit beeld geraken. De oudere medewerker uit de organisatie verwijderen lijkt dan de enige logische 'oplossing'.

Ten tweede werkt dit soort stereotypering vaak als een 'selffulfilling prophecy', resulterend in minder aandacht voor duurzame inzetbaarheid en minder loopbaanmogelijkheden, en vervolgens een geringere motivatie van oudere werknemers om daadwerkelijk te participeren in ontwikkelingsactiviteiten. Hiermee is de oudere werknemer dus kwetsbaar en ziet zichzelf als een problematische medewerker die als reactie hierop naar mogelijke vormen van compensatie zal gaan zoeken (bijv. minder verantwoordelijkheden, lagere standaarden, minder eisen en meer aanspraak op steun van anderen). Behalve dat dit de identiteit, gevoelens van eigenwaarde en het welbevinden aantast, leidt het ook tot verarming van hun functioneren, en vormt het hierdoor weer een voedingsbodem voor het in stand houden van de stereotypen.

\section{Organisatieniveau}

Op organisatieniveau zijn push-factoren voor oudere werknemers te onderscheiden die samenhangen met het organisatieklimaat, Human Resource-praktijken of personeelsinstrumenten en met de relatie met de leidinggevende.

\section{Negatieve relatie leidinggevende}

Een belangrijke push-factor voor oudere werknemers vormt een negatieve benadering door hun direct leidinggevende. De interacties tussen de leidinggevende en zijn of haar ondergeschikte en de relaties tussen collega's in een team of afdeling zijn van groot belang in het faciliteren van duurzame inzetbaarheid van werknemers. Een betere verhouding met de leidinggevende en een betere samenwerking binnen het team of de afdeling werkt positief op de motivatie en attitudes van oudere werknemers (Gellert \& Kuipers, 2008).

\section{HR-praktijken of personeelsinstrumenten}

Een andere belangrijke groep push-factoren heeft betrekking op het personeels- of Human Resources-beleid van organisaties. Onderzoek heeft aangetoond dat bepaalde HR-praktijken positief of negatief kunnen uitwerken op de duurzame inzetbaarheid van, met name, oudere 
werknemers. Kooij e.a. (2010) maken, in een meta-analyse van 83 studies, een onderscheid tussen twee soorten HR-praktijken: praktijken gericht op groei en ontwikkeling versus praktijken gericht op behoud of tegengaan van verlies. Meer specifiek blijkt uit hun onderzoek dat oudere werknemers positiever reageren op HR-praktijken die behoud van eigen niveau of flexibiliteit waarborgen (zoals flexibele werktijden, teamwerk) in vergelijking tot ontwikkelingsgerichte HR-praktijken (zoals nieuwe kennis en vaardigheden opgedaan in trainingen en doorgroeimogelijkheden).

\section{Taakniveau}

Op het taak niveau zijn push-factoren voor oudere werknemers te onderscheiden die inspelen op de veranderingen in cognitieve vermogens en fysieke reserves (cognitieve en fysieke taakeisen) en die een misfit weergeven tussen de oudere werknemer en zijn of haar werkomgeving.

\section{Cognitieve taakeisen}

Cognitieve taakeisen kunnen een grote belasting vormen voor de werknemer op hoge leeftijd. Het werk kan als mentaal te zwaar belastend worden beschouwd, bijvoorbeeld doordat een te groot beroep op handelingssnelheid wordt gedaan, of omdat men verschillende dingen naast elkaar moet doen. Hierbij is niet zozeer de hoge belasting op zich een probleem, maar vooral de manier waarop men daarmee omgaat. Zo is gebleken uit empirisch onderzoek dat werknemers die hun eigen handelen kritisch blijven bezien, en dit goed afstemmen op wat er vereist wordt, beter duurzaam inzetbaar zijn (Steemers, 2010). Het blijvend ontwikkelen van de zogenoemde cognitieve flexibiliteit stelt mensen in staat om hun mentale bagage actueel en relevant te houden en dit kan voorkomen dat men vastloopt in het werk.

\section{Fysieke taakeisen}

Een tweede groep van push-factoren betreft de mate van lichamelijke belasting door het werk. Nachtdiensten of fysiek zwaar werk kunnen een negatieve invloed hebben op iemands functioneren. Hierbij is het personeelsbeleid overigens van prominent belang. Veel organisaties bieden bijvoorbeeld de mogelijkheid om geen nachtdiensten meer te hoeven draaien als dat voor een bepaalde medewerker te belastend wordt. Voor functies die als lichamelijk zwaar worden beschouwd wordt soms een vaste 'ontslagleeftijd' gehanteerd, zoals bij de brandweer. In dergelijke functies is het vooral van belang om de 'employability' op peil te houden zodat iemand in staat is om een andere baan te kunnen vinden als het werk te zwaar wordt of als de ontslagleeftijd wordt bereikt.

\section{Persoon-Omgeving-misfit}

Volgens het Person-Environment Fit Model (zie - H. 2) is het van belang dat het gedrag en de attitudes en doelen van werknemers overeenkomen met de vereiste doelen in de werkomgeving. Volgens Wright en Hamilton (1987) zouden ouderen een voorsprong op jongeren moeten hebben in het realiseren van een effectieve persoon-omgeving-fit, omdat zij een beter zelfconcept en idee over de eigen inzetbaarheid hebben verkregen door de loopbaanervaringen die zij in de loop der tijd hebben opgedaan. Echter, eerder onderzoek toont aan dat ouderen problemen ondervinden in het inzetbaar blijven in complexe, snel veranderende werkomgevingen en op latere leeftijd weinig kans hebben op het vinden van een andere baan en ook lastig zelf een geschikte persoon-omgeving-fit kunnen creëren (Nauta e.a., 2004). Hierbij speelt ook de aard van het werk een rol: in specialistische functies blijkt met de leeftijd de inzetbaarheid voor andere functies sneller af te nemen dan in generieke functies. 


\section{Individueel niveau}

In par. 22.3 zijn de push-factoren op individueel niveau nader omschreven. Voorbeelden zijn: de kans op kwalificatieveroudering, negatieve veranderingen in cognitieve en fysieke mogelijkheden, en belastende levensloopveranderingen zoals mantelzorg voor zieke ouders of een hulpbehoevende partner (zie $\bullet$ Figuur 22.2).

Uit het overzicht van eerder empirisch onderzoek op het terrein van ouder worden en werk en uit • Figuur 22.4 wordt duidelijk dat een leven lang duurzaam inzetbaar blijven op het werk het resultaat is van een effectieve regulatie van zowel positieve als negatieve veranderingen en van diverse push-factoren die intern of in de sociale context van de medewerker plaatsvinden. Wanneer ouderen succesvol omgaan met deze push-factoren realiseren ze een effectieve duurzame inzetbaarheid, terwijl bij mogelijke problemen in de regulatie de gevolgen voor de ouderen uiteen kunnen lopen van herstelproblemen tot meer ernstige vormen als ziekte en uitval. - Figuur 22.4 geeft samenvattend het model voor duurzame inzetbaarheid van ouder wordende werknemers weer en visualiseert de push-factoren die een belangrijke rol spelen in de beslissing van werknemers om vroegtijdig de arbeidsmarkt te verlaten, dan wel langer door te gaan werken (Baltes e.a., 1999; Meijman \& Mulder, 1998).

\subsection{Interventies om duurzame inzetbaarheid van ouderen te bevorderen}

Bij het ontwerpen van een geschikte maatregel om duurzame inzetbaarheid te bevorderen kan een werkgever kiezen uit verschillende typen interventies. Om te beginnen kan gekeken worden naar de focus van de interventie: curatie, preventie of amplitie (zie $>$ H. 9). Bij curatie gaat het om het verhogen van een lage inzetbaarheid, bijvoorbeeld wanneer er sprake is van gezondheidsklachten of verzuim. Bij preventie gaat het om het voorkomen van een verminderde inzetbaarheid. Met amplitie worden interventies bedoeld die gericht zijn op het bevorderen van positieve indicatoren van duurzame inzetbaarheid van oudere werknemers, zoals gezondheid, welbevinden en bevlogenheid (Ouweneel e.a., 2009). Daarnaast kunnen interventies gericht zijn op kenmerken van de werknemer (zoals gezondheid, werkvermogen of aanpassingen in uit te voeren werk) of op de werkgever (zoals targets stellen voor werkgevers, bonussen voor werkgevers om ouderen aan te stellen), of op de combinatie van werknemer en werkgever(bijv. via op maat gemaakte afspraken tussen werknemer en werkgever) (DeLange e.a., 2011a). Uit het overzicht van Brouwer en collega's (2012) werd duidelijk dat in Nederland vooral gebruikgemaakt wordt van interventies gericht op preventie of curatie en dat het accent ligt op het ondersteunen of veranderen van het gedrag van de oudere werknemer.

Er is tot nu toe weinig tot geen kennis over 'evidence-based' interventies om de duurzame inzetbaarheid van oudere werknemers te faciliteren, omdat systematisch onderzoek naar de beschikbare interventies veelal ontbreekt (zie $>$ H. 9). Uit het overzicht van Brouwer en collega's (2012) wordt duidelijk dat de toegepaste interventies in te delen zijn naar drie specifieke invalshoeken, namelijk: loopbaanbeleid, arbeidsomstandigheden (inclusief gezondheidsbeleid), en interventies op het terrein van arbeidsvoorwaarden.

\section{Loopbaanbeleid}

De kern van dit type interventies zijn het behoud van flexibiliteit van oudere medewerkers en hun inzetbaarheid voor de organisatie op alle mogelijke manieren (Cuelenaere, Deckers \& Siegert, 2009; bijv. via functioneringsgesprekken, interne mobiliteit, opleiding of trainingen). Er zijn veel Nederlandse bedrijven die gebruikmaken van dit type interventie en de resultaten 
geven over het algemeen positieve trends weer voor het verhogen van de duurzame inzetbaarheid van ouderen.

\section{Arbeidsomstandighedenbeleid (inclusief gezondheidsbeleid)}

Bij interventies gericht op arbeidsomstandighedenbeleid ligt het accent op aanpassingen in de belasting van de medewerker door het werk, en tegelijkertijd op het vergroten van de belastbaarheid van de medewerkers (Cuelenaere e.a., 2009; bijv. ergonomische werkaanpassingen of gezondheidsadvies). Er zijn aanwijzingen dat het gebruik van ontziemaatregelen, zoals deeltijdpensioen, meer beschouwd moet worden als een eerste stap in de richting van pensionering dan als een stap om het arbeidzame leven te verlengen (Henkens e.a., 2009). Josten en Schalk (2010) vonden bijvoorbeeld zowel positieve als negatieve effecten van demotie als interventie onder werknemers ouder dan 45 jaar. Ouderen rapporteerden namelijk minder uitputting in geval van demotie naar fysiek minder zware functies, maar bleken tegelijkertijd significant minder tevreden te zijn met hun aangepaste functie. De volgende werkaspecten blijken van belang te zijn in het motiveren van oudere werknemers: (a) het aanbieden van intrinsiek motiverend werk (Kooij e.a., 2011); (b) HR-instrumenten die behoud van het eigen niveau mogelijk maken (zoals flexibiliteitsregelingen); (c) vervulde psychologische contracten (De Lange e.a, 2011b), en met name persoonlijke 'op maat gemaakte' werkafspraken tussen werknemer en werkgever die flexibiliteit voor een oudere werknemer waarborgen (zogenoemde flexibiliteit I-deals; De Lange e.a., 2011a).

\section{Arbeidsvoorwaarden}

Dit type interventies betreft maatregelen of acties op macroniveau die aanpassingen in beleid betekenen waardoor meer mogelijkheden worden geboden. of die ingrijpen op het type arbeid dat geboden kan worden (Cuelenaere e.a., 2009; zoals deeltijdpensioen, overbruggingsbanen, financiële bonussen of voorwaarden). Eerder onderzoek heeft positieve resultaten voor dit type interventie aangetoond op het verhogen van de duurzame inzetbaarheid van oudere werknemers (Brouwer e.a., 2012).

Veel onderzoekers benadrukken het belang van een integrale benadering in het beïnvloeden van de duurzame inzetbaarheid van oudere werknemers, waarbij zowel een werknemersals een werkgeversperspectief gehanteerd wordt om de diverse belangen te integreren in een nieuwe aanpak.

Hieronder staan wij stil bij een voorbeeld van een loopbaanbewust personeelsbeleid, getiteld model voor loopbaanlange fitheid (Nauta, De Lange \& Görtz, 2010), dat succesvol door de Politie Nederland als interventie is ingezet om de duurzame inzetbaarheid van hun personeel te faciliteren (zie - Tabel 22.2).

In het model voor loopbaanlange fitheid zijn de hierboven beschreven benaderingen van ouder worden op het werk, per type leeftijd (bijv. privésituatie), vertaald in preventieve ('Hoe kan ik mijn privéleven organiseren?') en curatieve vragen ('Hoe kan ik de werk-privédisbalans herstellen'), en naar behoeften die bij werknemers spelen, maar ook bij hun werkgevers spelen ('Hoe krijg ik toegewijde en betrokken medewerkers?'). Verder wordt er in het model een onderscheid gemaakt tussen maatwerkoplossingen op individueel (bijv. een cursus volgen gericht op het organiseren van het privéleven) versus werkgeversniveau (bijv. flexibele werktijden aanbieden). Nauta e.a. (2010) leggen uit dat werknemers zich bij de eerder behandelde verschillende typen leeftijden (professionele leeftijd, leefsituatieleeftijd, enz.) verschillende diagnostische vragen zouden moeten stellen, waardoor zij kunnen werken aan het voorkomen of oplossen van problemen. De verschillende typen 'leeftijden' zijn ook gerelateerd aan verschillende behoeftes van werkgevers, zoals de behoefte aan competente, toegewijde, gemotiveerde en 
Tabel 22.2 Model voor loopbaanlange fitheid bij de Nederlandse politie (Nauta, De Lange, \& Görtz, 2010)

\begin{tabular}{|c|c|c|c|c|c|c|}
\hline & $\begin{array}{l}\text { soort 'leef- } \\
\text { tijd' }\end{array}$ & $\begin{array}{l}\text { vakbe- } \\
\text { kwaamheid }\end{array}$ & $\begin{array}{l}\text { privésitu- } \\
\text { atie }\end{array}$ & $\begin{array}{l}\text { psycho- } \\
\text { sociale } \\
\text { beleving }\end{array}$ & gezondheid & $\begin{array}{l}\text { neurocog- } \\
\text { nitie }\end{array}$ \\
\hline \multirow[t]{5}{*}{$\begin{array}{l}\text { werkne- } \\
\text { mer }\end{array}$} & $\begin{array}{l}\text { behoefte } \\
\text { werknemer }\end{array}$ & $\begin{array}{l}\text { wil zich } \\
\text { bekwamen }\end{array}$ & $\begin{array}{l}\text { wil werk } \\
\text { en privé } \\
\text { flexibel } \\
\text { combine- } \\
\text { ren }\end{array}$ & $\begin{array}{l}\text { wil jong } \\
\text { ogen en } \\
\text { wijs over- } \\
\text { komen }\end{array}$ & $\begin{array}{l}\text { wil fit } \\
\text { blijven }\end{array}$ & $\begin{array}{l}\text { wil zich ont- } \\
\text { wikkelen }\end{array}$ \\
\hline & $\begin{array}{l}\text { kernvraag } \\
\text { aan zichzelf }\end{array}$ & 'Wat kan ik?' & $\begin{array}{l}\text { 'Hoe wil ik } \\
\text { leven?' }\end{array}$ & $\begin{array}{l}\text { 'Wat wil } \\
\text { ik?' }\end{array}$ & $\begin{array}{l}\text { 'Hoe blijf ik } \\
\text { fit?' }\end{array}$ & $\begin{array}{l}\text { 'Wat kan ik } \\
\text { leren?' }\end{array}$ \\
\hline & $\begin{array}{l}\text { zelfma- } \\
\text { nagement } \\
\text { (preven- } \\
\text { tief) }\end{array}$ & $\begin{array}{l}\text { vakinhou- } \\
\text { delijk leren } \\
\text { (verdiepen) }\end{array}$ & $\begin{array}{l}\text { privéleven } \\
\text { organiseren }\end{array}$ & $\begin{array}{l}\text { flexibel } \\
\text { opstellen }\end{array}$ & $\begin{array}{l}\text { veel bewe- } \\
\text { gen, gezond } \\
\text { eten }\end{array}$ & $\begin{array}{l}\text { breed leren; } \\
\text { veel bewe- } \\
\text { gen }\end{array}$ \\
\hline & $\begin{array}{l}\text { mogelijk } \\
\text { probleem }\end{array}$ & $\begin{array}{l}\text { vastroesten; } \\
\text { functie te } \\
\text { makkelijk, te } \\
\text { moeilijk of } \\
\text { niet-passend }\end{array}$ & $\begin{array}{l}\text { werk-privé- } \\
\text { disbalans }\end{array}$ & $\begin{array}{l}\text { negatief } \\
\text { zelfbeeld }\end{array}$ & $\begin{array}{l}\text { lichamelijke } \\
\text { klachten }\end{array}$ & $\begin{array}{l}\text { verminderd } \\
\text { leervermo- } \\
\text { gen }\end{array}$ \\
\hline & $\begin{array}{l}\text { probleem- } \\
\text { aanpak } \\
\text { (curatief) }\end{array}$ & $\begin{array}{l}\text { andere func- } \\
\text { tie zoeken }\end{array}$ & $\begin{array}{l}\text { werk en } \\
\text { privé leren } \\
\text { combine- } \\
\text { ren }\end{array}$ & $\begin{array}{l}\text { psychi- } \\
\text { sche hulp } \\
\text { zoeken }\end{array}$ & $\begin{array}{l}\text { medische } \\
\text { hulp zoeken }\end{array}$ & $\begin{array}{l}\text { hersentrai- } \\
\text { ning }\end{array}$ \\
\hline \multirow[t]{5}{*}{$\begin{array}{l}\text { werkgever } \\
+ \text { HR- } \\
\text { praktijken }\end{array}$} & $\begin{array}{l}\text { behoefte } \\
\text { werkgever }\end{array}$ & $\begin{array}{l}\text { wil juiste } \\
\text { persoon op } \\
\text { juiste plaats } \\
\text { (competent) }\end{array}$ & $\begin{array}{l}\text { wil toege- } \\
\text { wijde me- } \\
\text { dewerkers } \\
\text { (betrokken) }\end{array}$ & $\begin{array}{l}\text { wil gemo- } \\
\text { tiveerde } \\
\text { mede- } \\
\text { werkers } \\
\text { (gemoti- } \\
\text { veerd) }\end{array}$ & $\begin{array}{l}\text { wil laag } \\
\text { verzuim } \\
\text { (gezond) }\end{array}$ & $\begin{array}{l}\text { wil mede- } \\
\text { werkers } \\
\text { flexibel } \\
\text { inzetten } \\
\text { (inzetbaar) }\end{array}$ \\
\hline & $\begin{array}{l}\text { kernvraag } \\
\text { van mana- } \\
\text { ger }\end{array}$ & $\begin{array}{l}\text { 'Wat wil je } \\
\text { doen?' }\end{array}$ & $\begin{array}{l}\text { 'Hoe is het } \\
\text { thuis?' }\end{array}$ & $\begin{array}{l}\text { 'Hoe be- } \\
\text { valt het } \\
\text { hier?' }\end{array}$ & $\begin{array}{l}\text { 'Hoe is het } \\
\text { met je ge- } \\
\text { zondheid?' }\end{array}$ & $\begin{array}{l}\text { 'Wat wil je } \\
\text { leren?' }\end{array}$ \\
\hline & $\begin{array}{l}\text { manage- } \\
\text { ment (pre- } \\
\text { ventief) }\end{array}$ & $\begin{array}{l}\text { uitdagend } \\
\text { werk; loop- } \\
\text { baanmoge- } \\
\text { lijkheden }\end{array}$ & $\begin{array}{l}\text { flexibele } \\
\text { werktijden, } \\
\text { verlofre- } \\
\text { gelingen, } \\
\text { kinderop- } \\
\text { vang }\end{array}$ & $\begin{array}{l}\text { diversiteit } \\
\text { promo- } \\
\text { ten }\end{array}$ & $\begin{array}{l}\text { gezond } \\
\text { werk bieden }\end{array}$ & $\begin{array}{l}\text { ontwik- } \\
\text { kelings- en } \\
\text { opleidings- } \\
\text { mogelijkhe- } \\
\text { den }\end{array}$ \\
\hline & $\begin{array}{l}\text { mogelijk } \\
\text { risico }\end{array}$ & $\begin{array}{l}\text { onderpres- } \\
\text { tatie }\end{array}$ & $\begin{array}{l}\text { (mentaal) } \\
\text { verzuim }\end{array}$ & $\begin{array}{l}\text { demoti- } \\
\text { vatie }\end{array}$ & verzuim & $\begin{array}{l}\text { ervarings- } \\
\text { concentratie }\end{array}$ \\
\hline & $\begin{array}{l}\text { probleem- } \\
\text { aanpak } \\
\text { (curatief) }\end{array}$ & $\begin{array}{l}\text { her-en uit- } \\
\text { plaatsing }\end{array}$ & $\begin{array}{l}\text { extra verlof; } \\
\text { onder- } \\
\text { steuning } \\
\text { regelen }\end{array}$ & $\begin{array}{l}\text { stereo- } \\
\text { typen } \\
\text { bestrij- } \\
\text { den }\end{array}$ & $\begin{array}{l}\text { werk } \\
\text { aanpassen } \\
\text { aan beper- } \\
\text { kingen en } \\
\text { wensen } \\
\text { werknemer }\end{array}$ & $\begin{array}{l}\text { om-, bij-en } \\
\text { herscholing }\end{array}$ \\
\hline
\end{tabular}

Bron: Nauta, De Lange \& Görtz (2010). 
gezonde medewerkers. Om die behoeftes te kunnen managen, gaan leidinggevenden hierover idealiter in gesprek met hun medewerkers en kunnen bedrijven zowel preventief als curatief beleid opzetten. Dialoog en maatwerk zijn hierbij sleutelbegrippen. Diverse onderzoekers pleiten daarom tegen een leeftijdsbewust, maar voor een loopbaanbewust personeelsbeleid (Nauta e.a., 2010).

Samenvattend zou toekomstig beleid gericht op de duurzame inzetbaarheid van medewerkers gebaseerd moeten zijn op een integrale benadering waarin dialoog tussen werknemer en werkgever centraal staat. Hierbij zijn er belangrijke taken voor diverse spelers te onderscheiden. De oudere werknemer zelf dient zijn of haar duurzame inzetbaarheid te bewaken of te bevorderen door bijvoorbeeld een gezonde leefstijl te hanteren of medische behandeling te zoeken in geval van fysieke problemen. Daarnaast moeten werkgevers zich verantwoordelijk voelen voor de duurzame inzetbaarheid van het eigen personeel door deze regelmatig te monitoren (via onderzoek), en geschikte maatwerkmaatregelen aan te bieden die preventie of curatie mogelijk maken (zoals voldoende aanbod scholing, geschikte personeelsinstrumenten, gezond en veilig werk). Tot slot heeft de overheid de taak om wenselijke arbeidsvoorwaarden (zoals financiële bonussen voor werkgevers) en wetgeving te realiseren om zowel werknemers als werkgevers te ondersteunen in het realiseren van de duurzame inzetbaarheid in het heden, maar ook in de toekomst.

\section{Aanbevolen literatuur}

Brouwer, S., De Lange, A., Van der Mei, S., Wessels, M., Koolhaas, W., Bültmann, U., Van der Heijden, B., \& Van der Klink, J. (2012). Duurzame inzetbaarheid van de oudere werknemer: stand van zaken. Overzicht van determinanten, interventies en meetinstrumenten vanuit verschillende perspectieven. Hilversum: Stichting Instituut Gak.

De Lange, A.H., Ybema, J.F., \& Schalk, R. (2011). Stoppen of doorgaan? Theorie en praktijk van pensionering en langer doorwerken. Gedrag \& Organisatie, 24, 4, 323-341.

Schalk, R., Van Veldhoven, M., De Lange, A.H., De Witte, H., Kraus, K., Roßnagel,C., Tordera, N., Van der Heijden, B.I. J.M., \& Zappalà, S. e.a. (2010). Moving European research on work and ageing forward: Overview and agenda. European Journal of Work and Organizational Psychology, 19, 76-101.

Van der Heijden, B.I.J.M. (2011). Als het getij verloopt, verzet men de bakens. Inaugurele rede. Radboud Universiteit Nijmegen. 